Cahiers de recherches médiévales

\title{
Les passions dans les recueils de nouvelles
}

(XIV ${ }^{\mathrm{e}}-\mathrm{XVII}{ }^{\mathrm{e}}$ siècles)

\section{Bruno Méniel}

\section{(2) OpenEdition \\ Journals}

Édition électronique

URL : https://journals.openedition.org/crm/11534

DOI : $10.4000 / \mathrm{crm} .11534$

ISSN : 1955-2424

Éditeur

Honoré Champion

Édition imprimée

Date de publication : 15 juin 2009

Pagination : 293

ISSN : $1272-9752$

Référence électronique

Bruno Méniel, «Les passions dans les recueils de nouvelles », Cahiers de recherches médiévales [En ligne], 17 | 2009, mis en ligne le 26 mars 2009, consulté le 15 décembre 2022. URL : http:// journals.openedition.org/crm/11534; DOI : https://doi.org/10.4000/crm.11534 


\section{政 RM}

\section{Les passions dans les recueils de nouvelles (XIV ${ }^{\mathrm{e}}-\mathrm{XVII}{ }^{\mathrm{e}}$ siècles)}

Le recueil de nouvelles combine les vertus de la brièveté avec celles de l'ampleur: parce que la nouvelle vise la concision, elle parvient à être simple, efficace, édifiante; parce que le recueil obéit à un ordre voulu ou que se créent entre les récits des échos et des correspondances, il allie à la cohérence la complexité. Soucieuse du réel, la nouvelle présente l'homme assujetti aux affects et aux désirs. En raison de sa vivacité et de son exemplarité, elle a des affinités avec les passions : qu'elle les exalte ou les condamne, elle en fait souvent le moteur de l'action. Le recueil de nouvelles peut donc être lu comme une casuistique, psychologique et morale. Il n'est pas fortuit qu'il se répande en même temps que les collections d'exempla, les «sommes des péchés», les manuels de confesseurs... En tout cas, l'étude des nouvelles constitue une clef précieuse pour l'anthropologie du Moyen Âge et de la Renaissance. Philippe Guérin étudie ici la vergogna dans le Décaméron; Bénédicte Boudou s'interroge sur la place de la vengeance dans les Nouvelles Récréations et Joyeux Devis de Bonaventure Des Périers; Ricardo Saez examine avec attention le Jaloux d'Estrémadure de Cervantès.

Bruno Méniel

Cahiers de Recherches Médiévales, 17, 2009 